\title{
The Syntax of Tone in Guinean Kpelle
}

\author{
MARIA KONOSHENKO \\ Sholokhov Moscow State University for the Humanities ${ }^{1}$
}

\section{$1 \quad$ Introduction}

A major question challenging linguists who study the interaction between phonology and syntax is whether prosodic structure is organized as a syntax independent module of grammar with its own structure or whether there is one-to-one correspondence between prosody and syntax ${ }^{2}$. In recent years linguists have devised many theories addressing the issue, such as The Prosodic Hierarchy Theory (Selkirk 1980; Nespor and Vogel 1986 etc.), the Minimal Indirect Reference Model (Seidl 2001), Multiple Spell-Out Theory proposed by Dobashy (2003) and Ishihara (2003), Feature-chain Mapping Analysis presented by Elordieta (1997), the Match Theory of prosody-syntax interface (Selkirk 2009) - cf. Elordieta (2007) and Selkirk (2011) for up-to-date references. Unfortunately, most current studies of the phonology-syntax interface are based on rather limited typological sample. Concerning African languages, it is mostly Bantu languages that are discussed in literature - cf. (Downing 2013) for an overview.

In this paper I study the interaction between prosodic and syntactic structure in Guinean Kpelle (GK), an underdescribed Southwestern Mande tonal language spoken in West Africa, Republic of Guinea. My syntactic approach to GK is largely based on Nikitina's $(2009,2011)$ analysis of the Wan language. In this paper I focus on surface changes of tone in GK (the

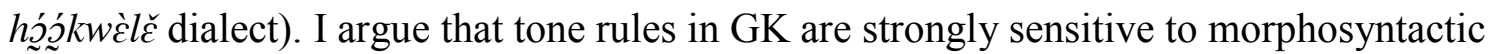
structure, and in most cases prosodic structure can be derived from syntactic structure in this language. In other words, GK gives evidence of a strong syntax-phonology correspondence supporting the "Match" model of phonology-syntax interface as argued in Selkirk $(2009,2011)$.

To my knowledge, Mande languages have never been discussed with respect to the phonology-syntax interface before. In this article I am going to introduce some new empirical data which might contribute to our understanding of the interaction between phonology and syntax.

\footnotetext{
1 This paper is written with financial support from the Russian Science Foundation, project 14-18-03270 "Word order typology, communication-syntax interface, and information structure in languages of the world". I am grateful to Valentin Vydrin (INALCO, Paris) and Larry Hyman (University of California, Berkeley) for their helpful criticism throughout my work on tone in Kpelle. I would also like to express my sincere gratitude to Davide Lama, Fassou Bienvenu Loua, and Jacques Achille Théa who became my language consultants - and friends.

2 Abbreviations: B - basic series; CONJ - conjugate auxiliary; DEF - definite; GK - Guinean Kpelle; H high tone; $(\mathrm{H})$ - floating high tone; HAB - habitual; $\mathrm{L}$ - low tone; NEG - negative; NF - non-finite form; P positive; PL - plural; PST - past; RES - resultative; SG - singular; STAT - stative marker. I follow African phonetic alphabet writing conventions in the paper: $j$ stands for [d3], $y$ stands for [j]. Tones are marked on all vowels including word-final $\eta$. Underlying tones are marked in the examples unless noted otherwise.
} 
GK is spoken by ca 460000 speakers (Lewis et al. 2014) in the Republic of Guinea. Its grammatical descriptions can be found in Casthelain (1952) and Lassort (1952); there is also a large dictionary by Leger (1975). Unfortunately, tones are not marked in these sources. William Welmers described the phonology of Liberian Kpelle including its tone system (Welmers 1962). A preliminary comparative description of tone systems in Kpelle dialects can be found in Konoshenko (2008). The data presented in this paper were collected during my field trips to Nzerekore, Guinea (2008, 2009), and also during a number of sessions with Kpelle speakers in Berkeley (2010) and Moscow (2012).

The paper is organized as follows. In section 1 I discuss some crucial syntactic properties of Mande languages including GK. Section 2 is dedicated to tonal inventory in GK. In section 3 I introduce tone rules in GK and describe the interaction between tone and syntax in the language. Section 4 concludes the paper.

\section{Some syntactic properties of Mande languages}

Mande languages have a cluster of unusual syntactic properties which are not typical for neighboring or related languages. These properties include strict SAuxOVX word order (Dryer and Gensler 2005; Creissels 2005; Nikitina 2009), clause-external postpositional phrases (Nikitina 2008), formally identical transitive and possessive constructions (Innes 1967), and the absence of double-object constructions (Creissels 2005). I would like to focus on the first two properties which are crucial for my analysis of tone in GK.

\subsection{Strict SAuxOVX order}

Mande languages have extremely rigid SAuxOVX word order. Subjects and direct objects always precede the verb, and all other arguments and adjuncts follow the verb. In the vast majority of TAM constructions in Mande the subject is followed by an auxiliary-like element encoding tense-aspect, mood, and polarity, but also person and number in some languages including GK. This auxiliary-like element is called "predicative marker" in literature on Mande, I follow this terminology here.

In the following example (1) from GK subject and direct object are expressed before the verb whereas the oblique argument appears after the verb and is expressed by a postpositional phrase.

GK (Southwestern Mande; personal field notes)

(1) Zìlènû àă wálî tèyě nè̀̀nû pó.

$\begin{array}{llllll}\text { zìlènû } & \text { àă } & \text { wálî } & \text { tèy } & \text { nè̀ेnû } & \text { pó } \\ \text { DEFlman } & \text { 3SG.RES.P } & \text { money } & \text { give } & \text { DEFlwoman } & \text { to }\end{array}$

'The man gave the money to the woman'. 
In (1) the predicative marker $\grave{a} a$ expresses resultative aspect, positive polarity, and third person singular. Historically, elements marking subject person and number appeared after subject pronouns had fused with "bare" predicative markers and were then reanalyzed as agreement markers (Vydrin 2010, 2012a; Konoshenko 2013). Also, there may be no subject noun phrase in a clause in GK, in this case the predicative marker encoding person and number has anaphoric interpretation. So GK is a pro-drop language. Not all Mande languages have predicative markers encoding person and number, and only some of them have the pro-drop feature but this difference is not very important for the present discussion.

As in Mande in general, in GK a direct object must be overt in a transitive clause. If there is no direct object, a clause is automatically interpreted as intransitive. In (2) from GK there is a direct object expressed by a pronoun $d \check{l}$. In (3) there is no direct object, and the clause is interpreted as intransitive (with a minor semantic shift: 'to see' $\rightarrow$ 'to be found').

Pépèè àă dĩ káá làà.

Pépèè àă dĩ káá làà
Pepe 3sG.RES.P they see
'Pepe saw them there'.

(3) Pépèè àă káá làà.

Pépèè àă káá làà
Pepe 3SG.RES.P see there
'Pepe was found there'.

Transitive vs. intransitive alternation is not morphologically marked on the verb. Thus (2) and (3) are instances of passive lability which is highly regular in Mande languages being at the same time a typological rarum (Letučij 2006).

\subsection{Clause-external postpositional phrases}

Recall from (1) that oblique arguments always follow the verb in GK and in Mande in general. Here I follow Nikitina $(2009,2011)$, who argues on the bases of Wan, a Southeastern Mande language, that in Mande, while direct objects always appear inside the verb phrase, oblique arguments always following the verb never form a syntactic constituent with it. Instead, they appear outside the verb phrase. Nikitina's crucial evidence comes from constructions with embedded verb phrases. I illustrate her point with some data from GK below. Consider (4-5):

(4) Gwî̀ káá gwèlìlóù hù.

gwî̀ káá gwèlìlóù hù 
DEFlbanana be DEF/pot in

'The banana is in the pot'.

(5) Pépèè wélí káá Héní bà.

[Pépèè wélí $]_{\mathrm{NP}}$ káá Héní bà

Pepe love be Heni on

'Heni loves Pepe', lit. 'Pepe's love is on Heni'.

In (4) a simple locative construction with the verb káá 'be' and a postpositional phrase is given. In (5) the same construction is used metaphorically to denote one's love for someone. Here the head of the noun phrase is a relational noun wéli 'love', and its dependent Pépèe denotes the stimulus. The experiencer is expressed by the postpositional phrase Héní bà.

The examples below show that an embedded verb can also appear as a dependent of the relational noun.

(6) Kónóń mî̌ wélí káá Héní bà.

[[kónóń mìn $]_{\mathrm{VP}}$ wélí $]_{\mathrm{NP}}$ káá Héní bà

food eat love be Heni on

'Heni loves eating (food)'.

(7) Wálî tèyě wélí káá Héní bà núâ pó.

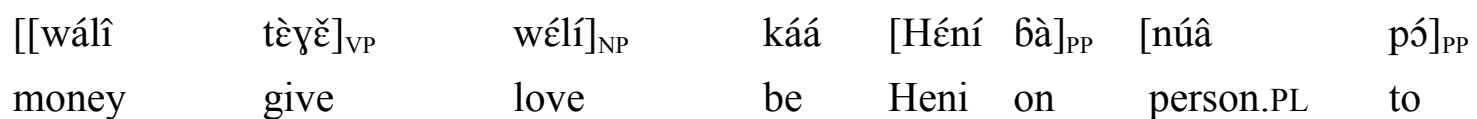

'Heni loves giving money to people'.

In (6) a transitive verb miľ 'eat' is embedded into the noun phrase, its direct object kónóń 'food' precedes the embedded verb, and the head noun wél $i$ 'love' follows the whole embedded verb phrase. In (7) the embedded verb tèyě 'give' has a direct object wálî 'money' and a postpositional argument denoting the recipient núâ p' 'to people'. Crucially, the postpositional phrase is not adjacent to the embedded verb, nor does it immediately follow to the noun phrase; it follows the postpositional phrase Héní bà 'on Heni' selected by the verb káá 'be'.

The data from GK suggest that postpositional phrases are not part of the verb phrase in these languages, rather they are independent constituents which follow the verb phrase.

The syntactic structure of a clause with a postpositional phrase in Mande and, specifically, in Kpelle is captured by the tree in (8) - cf. Nikitina (2009:920-921) for details and refinements. As noted in 1.1, GK is a pro-drop language, i.e. subject noun phrase may be absent in a clause so it is put in parentheses in (8). 
(8)

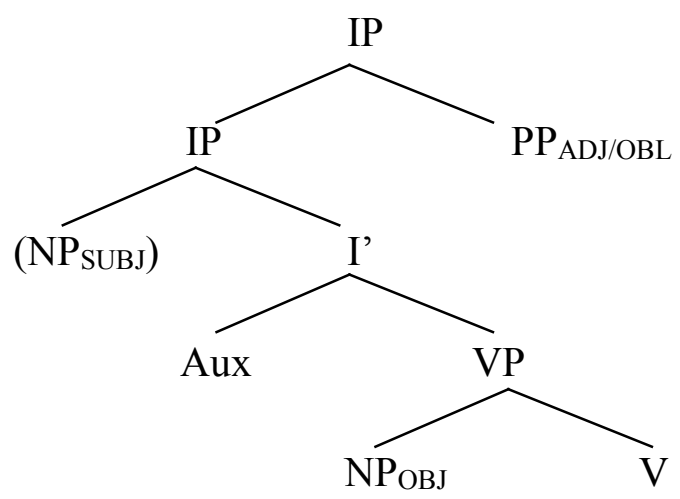

Finally, to give the reader a more complete idea of Mande clause structure, I must note that there are three possible slots for adverbial modifiers in Mande.

First, adverbs appear after the verb phrase either following or preceding postpositional phrases as in (9ab) from GK. Second, an adverbial modifier can appear in sentence-initial topic position (9c) but I do not discuss such cases in this paper.

(9a) Đă hwàà Héní bà kèlèkèlè.

yă hwàà $\quad\left[\begin{array}{lll}\text { Héní } & \text { bà }\end{array}\right]_{\mathrm{PP}}[\mathrm{kè̀lèkèlè}]_{\mathrm{AdvP}}$

1SG.HAB.P speak ${ }_{\text {HAB }}$ Heni on often

'I often scold Heni'.

(9b) = ᄁă hwàà kèlèkèlè HÉní bà

(9c) = kèlèkèlè yă hwàà Héní bà

Adverbial lexemes usually differ in their distribution depending on their form and semantics in a given language. In some languages including GK, a closed list of temporal adverbs can appear between the auxiliary and the verb:

(10) Pépèè è wéí pà.

\begin{tabular}{|c|c|c|}
\hline$[\text { Pépèè }]_{\mathrm{NP}}$ & [è & {$\left[[\mathrm{w} \varepsilon \hat{1}]_{\mathrm{AdvP}}\right.$} \\
\hline Pepe & 3SG.B.P & yesterday \\
\hline
\end{tabular}

We can now modify the tree in (8) by adding the positions for adverbial modifiers cf. $(11)^{3}$ :

3 In Manden languages, e.g. Bambara, some adverbs appear between direct object and verb (Vydrin 2012b) but this seems to be a specific feature not attested in other groups in Mande family. 
(11)

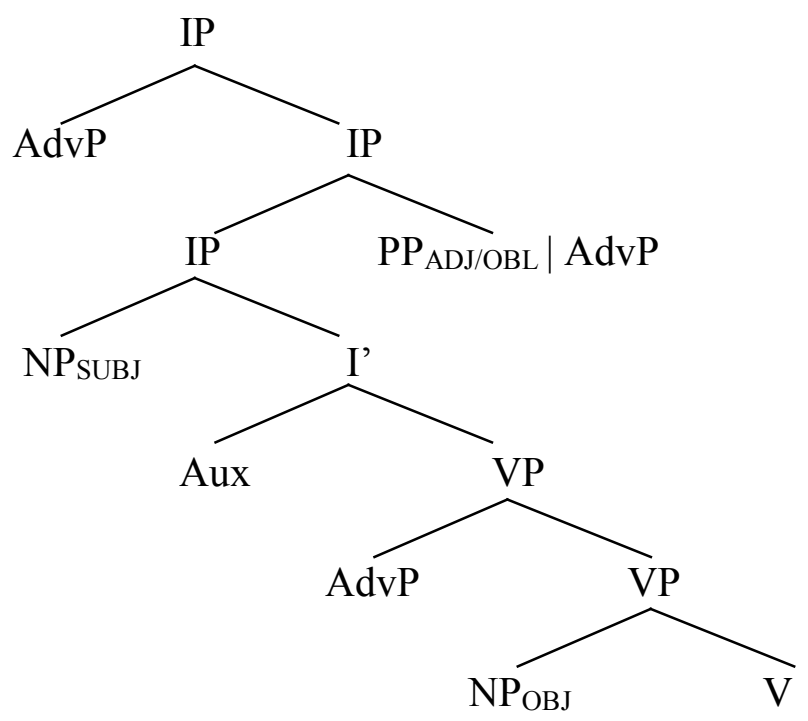

\section{Tonal inventory in Guinean Kpelle}

In this section I give basic information on the tonal inventory at the word level in GK (the háśkwèlě dialect). I also discuss the difference between lexical and morphological tones in the language.

As seen in (12ab), there is a $\mathrm{H}$ vs. $\mathrm{L}$ contrast in GK.

(12a) báá 'to kill me'

(12b) bàă 'to kill him'

The two tonal elements $\mathrm{H}$ and $\mathrm{L}$ make up six fixed lexical patterns, or melodies: $/ \mathrm{H} /$, $/ \mathrm{L}(\mathrm{H}) /, / \mathrm{LHL} /, / \mathrm{HL} /, / \mathrm{L} /$, and marginal /LH/. In this paper I will adopt the convention of representing tonal melodies in slashes: the $/ \mathrm{H} /$ melody. Tonal elements are written without brackets: $\mathrm{H}$ tone. $(\mathrm{H})$ represents a floating $\mathrm{H}$, which always follows a linked $\mathrm{L}$ in a $/ \mathrm{L}(\mathrm{H}) /$ melody. It is marked with a haček on the vowel or word-final $\eta$ : pàă 'to kill'; hò̆ 'to catch'. Phonetically, $/ \mathrm{L}(\mathrm{H}) /$ is realized as low level tone - I mark it as $\left[\mathrm{L}^{\circ}\right]$ in the phonetic transcription. For the sake of clarity, the conventions for $/ \mathrm{L}(\mathrm{H}) /$ are represented in (13):

$$
\begin{aligned}
& \text { Underlying: } \quad / \text { paa/ } \quad \text { Orthographic: pàă Phonetic: [pàa }{ }^{\circ} \text { (level L) } \\
& \text { L } \quad \mathrm{H}
\end{aligned}
$$

The /L(H)/ vs. /L/ contrast is neutralized before $\mathrm{H}$ tone: gbònǒ káá [gbònò káá] 'see a trap'; gbònò káá [gbònò káá] 'see a ring'. The two melodies are contrasted, however, before a pause (or in isolation) and when followed by $\mathrm{L}$ tone. In the former case, $/ \mathrm{L}(\mathrm{H}) /$ is realized as low level tone $\left[\mathrm{L}^{\circ}\right]$, whereas $/ \mathrm{L} /$ sounds as low falling tone: gbònǒ [gbònò ${ }^{\circ}$ ] 'trap' vs. gbònò [gbònö] 
'ring'. In the latter case, $/ \mathrm{L}(\mathrm{H}) /$ is pronounced $[\mathrm{LH}]$ with $(\mathrm{H})$ linked to the last syllable of its TBU (cf. Rule 4 in 3.4) whereas /L/ sounds as low level tone: gbònó hwèèlě [gbònó hwè̀l $\grave{\varepsilon}^{\circ}$ ] 'two traps' vs. gbònò hwèèlě [gbònò ${ }^{\circ}$ hwèèl $\dot{\varepsilon}^{\circ}$ ] 'two rings'.

The TBU of the melodies is the phonological foot: CV, CVV, CVy, CVVy, CVCV, CVCVV, CVCVy, and CVCVVy. Judging by the distribution of segments and tones on different feet, $\mathrm{CV}$ is monosyllabic since it never bears /LHL/ and /LH/ melodies. /L(H)/ is, however, possible on CV: $d \check{l}$ 'they'; mŭ 'underside of an object'. /HL/ can only appear as contextual on $\mathrm{CV}$. The other feet are bisyllabic with the first syllable being always monomoraic (CV-V; CV$\mathrm{Vy}$; CV-CV etc.). The most frequent structures in the dictionary are $\mathrm{CVV}, \mathrm{CVCV}$, and CVCVy. Other structures are also attested, i.e. CVVCV, CVVCVV, CVCVCV: hwè̀lě 'two', hààbă 'three', tè̀ेhwè̀̀ 'plain', hwè̀̀làa 'thin', bilihhî 'devil', bóbilì 'fetish' etc. Such items reveal fewer combinatory restrictions on tones and segments, and I analyze them as containing two or three feet.

/HL/ melody is realized as H-L on CVV structure: $k w \hat{\imath} \mathbf{l}$ 'night', and as H-HL on CVCV: yilê 'dog'.

GK is strongly isolating, so the phonological foot most often corresponds to morpheme and also to lexeme or word in this language ${ }^{4}$. Some examples with tonal melodies are given in Table 1.

Table 1: Tonal patterns in GK

\begin{tabular}{|c|c|}
\hline$/ \mathrm{H} /$ & bá 'rice’, káá ‘see’, bówá ‘knife’, tálááý ‘slip’ \\
\hline$/ \mathrm{L}(\mathrm{H}) /$ & $d \check{l}$ 'they', pàă 'to kill'; yàlă 'lion' kwènèč 'eggplant', \\
\hline$/ \mathrm{HL} /$ & kwîl 'night', yílê 'dog', gbánáà 'fusil' \\
\hline /LHL/ & 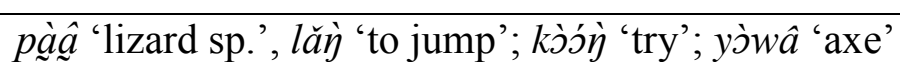 \\
\hline$/ \mathrm{L} /$ & 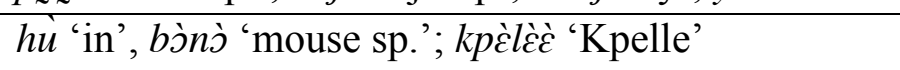 \\
\hline$/ \mathrm{LH} /$ & gòhó 'cribble', kpèćn 'cowrie'; mànáý 'manioc' \\
\hline
\end{tabular}

As noted above, $/ \mathrm{LH} /$ is marginal. It is only attested on non-relational nouns, and it never undergoes any phonological changes of tone since it never appears in those contexts where lexical tones on nouns may change (head of NP encoding inalienable possession).

Verbs and relational nouns can only have lexical/H/, /L(H)/, /HL/, and /LHL/. However, verbs in some TAM constructions and head nouns in some types of noun phrases are morphologically marked with $/ \mathrm{L} /$. In this case lexical tones of the word are suppressed by morphologically assigned /L/ - cf. the term "replacive tone" in Welmers (1973:132). For example, in a stative construction the verb kślśn 'know' appears with its lexical /H/ melody (14), whereas in the aorist construction it is /L/-marked (15).

$4 \quad$ Bimorphemic feet with grammatical suffixes are also possible, e.g. in nominalized verb forms: $y \varepsilon ́ l \varepsilon ́-i$ laugh-NF 'laughing'. 
(14) Đé Pépèè kólóń.

yé Pépèè kólóń
1sG.B.P Pepe know
'I know Pepe'.

(15) Đé Pépè̀̀ kòlò̀̀.

yé Pépèè kòlòn

1SG.B.P Pepe knowlPST

'I used to know Pepe'.

It is important to note that, like lexical melodies, morphologically assigned melodies may, in their turn, undergo purely phonological changes discussed in the following subsections. This is captured in (16): at Step 1 a word may change its lexical melody to morphological melody if required by grammatical construction; at Step 2 the resulting melody becomes an input for phonological changes.

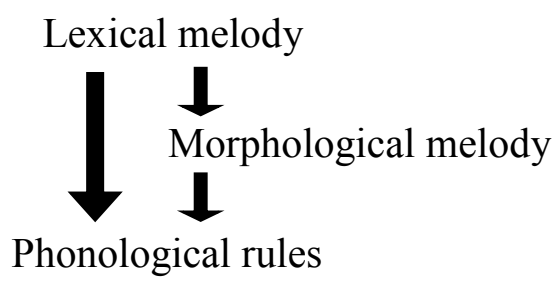

A notable difference between Step 1 and Step 2 is that at Step 1 the lexical melody is completely deleted and replaced by morphological melody, whereas at Step 2 the underlying tone leaves some traces at the surface level.

In the remainder of this paper I do not distinguish between lexical and morphological tonal melodies and I call both phenomena underlying, or input, melodies because they function identically as input for phonological rules. I use the term "tone rule" to denote phonological, or assimilatory, rules. In the examples below underlying melodies are given in slashes, and surface melodies are put in square brackets.

\section{Tone rules and syntax in GK}

In this section I discuss the tone rules in GK. I show that these rules are strongly conditioned by syntactic structure in the language though some instances of syntax-independent prosodic phrasing are also attested.

There are four major tone rules in GK: $\mathrm{H}$ tone spread on $/ \mathrm{L} / \mathrm{H}$ tone spread on $/ \mathrm{L}(\mathrm{H}) /$, contour simplification, and regressive linking of $(\mathrm{H})$. Note that there is no $\mathrm{H}$ spread onto /LHL/. 
The domain of the first two rules is a syntactic constituent, the domain of the second pair of rules is clause. These rules are discussed in subsections 3.1-3.4.

\subsection{Rule 1: $\mathrm{H}$ tone spread on /L/}

$\mathrm{H}$ tone, either linked or floating, spreads on the following /L/ melody which becomes [HL]. This is formalized in (17) and illustrated in (18-20):

$$
\begin{array}{lll}
/ \mathrm{L} / \rightarrow[\mathrm{HL}] / \mathrm{H} \_ & \\
/ \text {béláá kàà } / \rightarrow \text { [6éláá káà] } & \text { 'saw a sheep' } & / \mathrm{H} /+/ \mathrm{L} / \rightarrow[\mathrm{H}]+[\mathrm{HL}] \\
/ \text { bòlǔ kàà } / \rightarrow \text { [6òlù káà] } & \text { 'saw a goat' } & / \mathrm{L}(\mathrm{H}) /+/ \mathrm{L} / \rightarrow[\mathrm{L}]+[\mathrm{HL}] \\
\text { /nààlèè kàà } / \rightarrow \text { [nààlèè kàà] } & \text { 'saw a cat' } & / \mathrm{L} /+/ \mathrm{L} / \rightarrow[\mathrm{L}]+[\mathrm{L}]
\end{array}
$$

Underlying /L/ melody becomes surface [HL] on the verb kàà after béláá with /H/ in (18) and after $6 \grave{l}$ ǔ with /L(H)/ in (19). There is no change in (20), as it shows a combination of two /L/ melodies.

This rule applies within phonological phrases corresponding to syntactic constituents: the verb phrase [NP $\left.\mathrm{NBJ}_{\mathrm{OJ}} \mathrm{V}\right]_{\mathrm{VP}}$ as in $(18-19)$, the noun phrase $\left[\mathrm{NP}_{\mathrm{GEN}} \mathrm{N}\right]_{\mathrm{NP}}$ expressing non-anchoring relationship - in a sense of Koptievskaya-Tamm (2006), where the head noun is marked with /L/ as in (21), and the postpositional phrase [NP P] $]_{\mathrm{PP}}-\mathrm{cf}$. (22).

(21) /kwíi wòò/ $\rightarrow$ [kwíí wóò] 'the French language' (lit. 'language of white people')

(22) /béláá mù/ $\rightarrow$ [6éláá mû] 'under a sheep'

In all the cases represented above it is the syntactic head that undergoes the change $-\mathrm{V}$,

\begin{tabular}{|c|c|c|c|}
\hline yé & {$\left[[\text { Pépèè }]_{\mathrm{NP}}\right.$} & kóyó] $]_{\mathrm{NP}}$ & kàà \\
\hline 1 SG.B.P & Pepe & leg & see \PST \\
\hline
\end{tabular}
$\mathrm{N}$, or $\mathrm{P}$. The dependent phrase can contain a single word as in (18-19;21-22), or it may branch as in (23).

'I saw Pepe's leg'.

Interestingly, Rule 1 always applies between an auxiliary and a verb without direct object though, apparently, they do not form a syntactic constituent: 
(24) /ká pà/ $\rightarrow$ [ká pâ] 'you (pl.) came'; *[ká pà]Moreover, H tone spreads from an adverb to a verb when the former immediately precedes the non-branching verb phrase - cf. the tree in (11):

(25) /ká wéí pà/ $\rightarrow$ [ká wéí pâ] 'you (pl.) came yesterday’

(26) /yé kèlèě pà/ $\rightarrow$ [yé kèlèè pâ] 'I came today'

Non-branching verb phrase thus turns out to be accessible for $\mathrm{H}$ tone spread from an auxiliary as well as an adverb. In other words, both an auxiliary and an adverb appear to form phonological phrases with the verb which do not correspond to syntactic structure. This is one of few instances of prosody-syntax discrepancy I have discovered in GK so far. This is why it is not unreasonable to postulate separate phonological and syntactic phrases in GK which, however, correspond to each other to a large extent.

Crucially, however, $\mathrm{H}$ spread on /L/ never occurs between subject noun phrase and auxiliary (27), between auxiliary and object noun phrase (28), between verb and postpositional phrase (29) or adverbial modifier (30). The relevant pairs of syntactic elements are underlined in the examples below.

(27) /é lóń è nààlèè hèyè / $\rightarrow$ [é lóń è nààlèè hèyè]; *[é lóń ê nààlèè hèyè]

$\begin{array}{lllll}{[\text { é }} & \text { lóń }]_{\mathrm{NP}} & {[\mathrm{è}} & \text { [nààlèè } & \left.\text { hèyè }]_{\mathrm{VP}}\right]_{\mathrm{I}} \text {, } \\ 2 \mathrm{SG} & \text { child } & \text { 3SG.B.P } & \text { cat } & \text { takelPST }\end{array}$

'Your child took a cat'.

(28) /Pépèè ă kòyò hèyè/ $\rightarrow$ [Pépèè ă kòyò hèyè]; *[Pépèè à kóŷ̂ hèyè]

$\begin{array}{llll}{[\text { Pépèè }]_{\mathrm{NP}}} & {[\text { ă }} & {[\text { kòyò }} & \left.\text { hèyè }]_{\mathrm{VP}}\right]_{\mathrm{I}}, \\ \text { Pepe } & \text { 3SG.HAB.P } & \text { calabash } & \text { takelPST }\end{array}$

'Pepe takes a calabash (usually)'.

(29) /yàă jààlèè káá kpòyò hù/ $\rightarrow$ [yàá jààlèè káá kpòyò hù]; *[yàá jààlèè káá kpóyô hù]

$\left[\left[\text { yàă } \quad[\text { nààlèè káá }]_{\mathrm{VP}}\right]_{\mathrm{I}}\right]_{\mathrm{IP}} \quad[\text { kpòyò hù }]_{\mathrm{PP}}$

1SG.HAB.P cat see box in

'I saw a cat in a box'.

(30) /yàă jààlè̀ káá làà/ $\rightarrow$ [yàá nààlèè káá làà]; *[yàá jààlèè káá láà]

$\left[\left[\text { yàă } \quad[\text { nààlè̀ káá }]_{\mathrm{VP}}\right]_{\mathrm{I}}\right]_{\mathrm{IP}} \quad[\text { làà }]_{\mathrm{AdvP}}$

1SG.HAB.P cat see there 
'I saw a cat in there'.

\subsection{Rule 2: H tone spread on $/ \mathrm{L}(\mathrm{H}) /$}

Similarly to Rule 1 , linked or floating $H$ tone spreads on $/ \mathrm{L}(\mathrm{H}) /$. The applicability of the rule as well as the resulting melody, however, depend on the syntactic environment where the tonal combination in question occurs.

$\mathrm{H}$ can spread on the verb bearing $/ \mathrm{L}(\mathrm{H}) /$ in the verb phrase $\left[\mathrm{NP} \mathrm{OBJ}_{\mathrm{V}} \mathrm{V}\right]_{\mathrm{VP}}$. The resulting melody is $/ \mathrm{H} /$ :

$$
/ \mathrm{L}(\mathrm{H}) / \rightarrow[\mathrm{H}] / \mathrm{H}_{-}
$$

/6éláá hèyě/ $\rightarrow$ [6éláá héyé] 'take a sheep'

$$
/ \mathrm{H} /+/ \mathrm{L}(\mathrm{H}) / \rightarrow[\mathrm{H}]+[\mathrm{H}]
$$

/6òlǔ hèyě/ $\rightarrow$ [Gòlù héfé] 'take a goat'

$$
/ \mathrm{L}(\mathrm{H}) /+/ \mathrm{L}(\mathrm{H}) / \rightarrow[\mathrm{L}]+[\mathrm{H}]
$$

/nààlèè hèyě/ $\rightarrow$ [nààlèè hèyè'] 'take a cat'

$$
/ \mathrm{L} /+/ \mathrm{L}(\mathrm{H}) / \rightarrow[\mathrm{L}]+\left[\mathrm{L}^{\circ}\right]
$$

In (32) underlying /L(H)/ of the verb hèyě becomes [H] after H in béláá. In (33) floating $\mathrm{H}$ of bòlu triggers the change on $/ \mathrm{L}(\mathrm{H}) /$ of the verb. There is no change in (34) as there is no $\mathrm{H}$ preceding $/ \mathrm{L}(\mathrm{H}) /$ melody in this example.

The same rule applies within a combination of auxiliary and non-branching verb phrase (35) except for resultative -àă auxiliaries (36); it is also banned after adverbs (37) - instead, another rule applies in (36-37), cf. 3.4.

\begin{tabular}{|c|c|c|c|c|}
\hline [yàă & {$\left[[\text { kèlèě }]_{\mathrm{Adv} P}\right.$} & $\left.\left.\left[1 \grave{\sim}_{\text {čă}}\right]_{\mathrm{VP}}\right]_{\mathrm{VP}}\right]_{\mathrm{I}}$, & [wálî & bà $]_{\mathrm{PP}}$ \\
\hline 1 SG.RES.P & today & forget & money & on \\
\hline
\end{tabular}

(35) /ě kùlǒ/ $\rightarrow$ [è kúló] 'let him go!'

(36) /àă kùlǒ/ $\rightarrow$ [àá kùlò ${ }^{\circ}$ 'he has gone away'

(37) /yàă kèlèě lęcă wálî bà/ $\rightarrow$ [yàá kèléé lęà̀ wálí bà]; *[yàá kèlèè lẽ્á wálí bà]

Interestingly, Rule 2 only applies when verb phrase is part of the finite clause. Whenever it is embedded into a noun phrase, $\mathrm{H}$ does not spread on $/ \mathrm{L}(\mathrm{H}) /$. This is illustrated in (38), example (6) from subsection 1.2 is repeated here as (39):

/yàă kónóń mì̌/ $\rightarrow$ [yàà kónóý míí]

$\left[\left[\text { yàă } \quad[\text { kónóń mì̌ }]_{\mathrm{VP}}\right]_{\mathrm{I}}\right]_{\mathrm{IP}}$

1SG.RES.P food eat

'I've eaten (food)'. 
$(39)=(6)$

/kónóń mì̀ wélí káá Héní bà/ $\rightarrow$ [kónóý mì̀ wélí káá Héní bâ]

\begin{tabular}{|c|c|}
\hline & $\begin{array}{ll}\text { mî̀ }_{\mathrm{VP}} & \text { wélí1 }]_{\mathrm{NP}} \\
\text { eat } & \text { love }\end{array}$ \\
\hline
\end{tabular}

'Heni loves eating (food)'.

In (38) the verb is in the finite clause so the rule applies but there is no change in (39) where the verb phrase is embedded into the noun phrase.

Also, Rule 2 does not apply if the verb with /L(H)/ melody has a nominalizing suffix -i/zì (for stems with final $-\eta$ ) in progressive and some other constructions. The suffix triggers floating $(\mathrm{H})$ linking on the last syllable of the verb; and then $\mathrm{H}$ spread on the verb is blocked. This is illustrated in (40-41):

(41) /Héní káá wèlě tòǒ-ì/ $\rightarrow$ [Héní káá wèlě tòôì]; *[Héní káá wèlě tóóì]

Héní káá wèlě tòò-ì

Heni be song make-NF

'Heni is singing a song'.

$\mathrm{H}$ does not spread on $/ \mathrm{L}(\mathrm{H}) /$ in postpositional phrases (42), nor does it spread in noun phrases $\left[\mathrm{NP}_{\mathrm{GEN}} \mathrm{N}\right]_{\mathrm{NP}}$ expressing inalienable possession where head and dependent noun phrases are juxtaposed (43). The only exception I am aware of is the noun lèe 'mother' which gets [HL] melody after $\mathrm{H}(44)^{5}$.

(42) /kpélín mèì/ $\rightarrow$ [kpélín mè̀ ]; *[kpélíń méì] 'on a chair'

(43) /é kòlı̌/ $\rightarrow$ [é kòlò ] 'your skin'

(44) lé lèè/ $\rightarrow$ [é léè] 'your mother'

Another theoretically possible context for Rule 2 is a combination of noun and a nominal modifier within a noun phrase ${ }^{6}$. Adjective is a very marginal part of speech in GK, and no lexical $/ \mathrm{L}(\mathrm{H}) /$ was attested in this class. Instead, verbs in a stative form and numerals normally appear as

5 In another dialect of GK I am familiar with, tón’́nààlóì, all head nouns with lexical /L(H)/ melody occurring in a noun phrase $\left[\mathrm{NP}_{\mathrm{GEN}} \mathrm{N}\right]_{\mathrm{NP}}$ change their melody to [HL] after H: /é kòlǒ/ $\rightarrow$ [é kólô] 'your skin'. For some nouns the rule applies optionally: /é hùyǔ/ $\rightarrow$ [é húyû] or [é hùyù] 'your clan'.

$6 \quad$ Since modifiers cannot have /L/ melody in GK, I did not discuss this case for Rule 1. 
nominal modifiers, they always follow the head noun. However, Rule 2 never applies in such cases as shown in (45-46):

(45) / / Géláá kwèlèč/ $\rightarrow$ [6éláá kwèlè $\left.{ }^{\circ}\right]$

béláá kwèlě- $\varepsilon$

sheep be.white-STAT

'white sheep'

(46) /6éláá hwèèlě/ $\rightarrow$ [6éláá hwèèlè๋ ] 'two sheep'

The information on Rule 1 and Rule 2 is summarized in Table 2.

Table 2: $\mathrm{H}$ tone spread on $/ \mathrm{L} /$ and $/ \mathrm{L}(\mathrm{H}) /$

\begin{tabular}{|l|c|c|}
\hline Syntactic context & Rule 1: H tone spread on /L/ & Rule 2: H tone spread on $/ \mathrm{L}(\mathrm{H}) /$ \\
\hline$\left[\mathrm{NP}_{\mathrm{OBJ}} \mathrm{V}\right]_{\mathrm{VP}}$ & yes & yes/no (depending on the context) \\
\hline$\left[\mathrm{NP}_{\mathrm{GEN}} \mathrm{N}\right]_{\mathrm{NP}}$ & yes & no \\
\hline$[\mathrm{NP} \mathrm{P}]_{\mathrm{PP}}$ & yes & no \\
\hline$\left[\right.$ Aux $[\mathrm{VP}]_{\mathrm{I}}$ & yes & yes \\
\hline$\left[\mathrm{Adv}[\mathrm{VP}]_{\mathrm{VP}}\right.$, & yes/no $($ optional $)$ & no \\
\hline
\end{tabular}

It is interesting to note that $/ \mathrm{L} /$ melody relevant for Rule 1 is always morphologically assigned (except for postpositions which can have lexical/L/) and it is more accessible for surface change. $/ \mathrm{L}(\mathrm{H}) /$ melody is always lexical and it only changes on the verb, so Rule 2 depends on the head's part of speech.

\subsection{Rule 3: Contour simplification}

I use the term "Contour simplification" (CS) to denote a process whereby any word final falling sequence HL becomes [H] (to make it clear, by "word" I refer to syntactic word here). There are two subcases here as presented in (47-53):

(48) /6î̀ hù/ $\rightarrow$ [bíí hù] 'in a bag'

(49) /yílê kàà/ $\rightarrow$ [yílé kàà] 'saw a dog'

(50) /dà6álî hèyě/ $\rightarrow$ [dà6álí hèyè ${ }^{\circ}$ 'take the table'

(51) $\mathrm{HL}+\mathrm{H} \rightarrow[\mathrm{H}]+![\mathrm{H}]$

(52) /dàbálî jé/ $\rightarrow$ [dà6álí !nć] 'on the table' 
When word final HL is followed by $\mathrm{L}$ - which can be /L/, /L(H)/,/LHL/, or /LH/, its L is absorbed into the following $\mathrm{L}$ (47-50). When followed by $\mathrm{H}-/ \mathrm{H} /$ or $/ \mathrm{HL} /$, final $\mathrm{L}$ of the contour is deleted, and the next $\mathrm{H}$ is downstepped (51-53).

Rule 3 can also operate on the output of the Rule 1. The output of Rule 1 is [HL] which becomes input for Contour simplification (55-58) unless the contour is before a pause (54):

/yé pà/ $\rightarrow$ [yé pâ] (H spread on /L/) 'I came'

/yé pà làà/ $\rightarrow$ [yé pâ làà] (H spread on /L/) $\rightarrow$ [yé pá làà] (CS) 'I came there'

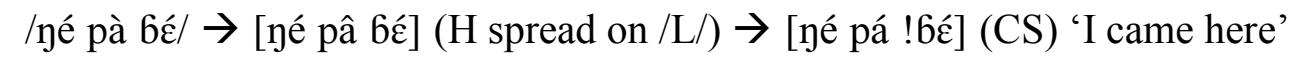
rejected Hehe'

/é lènè Pépèè 6à/ $\rightarrow$ [é lénê Pépèè bà] $(\mathrm{H}$ spread on /L/) $\rightarrow$ [é léné !Pépèè bà] (CS) 'you rejected Pepe'

Speaking in terms of rule interaction, we can say that Rule 1 and in some cases Rule 2 feed Rule 3 creating more contexts, i.e. HL contours on which Rule 3 operates.

Contour simplification applies within and across syntactic boundaries - e.g. between verb phrase and adverbial modifier (55-56), between verb phrase and postpositional phrase (5758 ) etc. Its syntactic domain is a clause, or intonation phrase in prosodic terms.

\subsection{Rule 4: regressive $(H)$ linking}

When $/ \mathrm{L}(\mathrm{H}) /$ is followed by $\mathrm{L}$ which can be in fact /L/, /L(H)/, /LHL/, or /LH/, the lexical floating tone becomes regressively linked to the last syllable of the word as in $(59-61)^{7}$ :

\footnotetext{
7 In fact, the way to formulate this rule strongly depends on our assumptions about the underlying melody of the second tonal pattern in Table 1 - namely, $/ \mathrm{L}(\mathrm{H}) /$ or $/ \mathrm{LH} /$. In this paper I argue that the underlying, or the main allotone of this pattern is $/ \mathrm{L}(\mathrm{H}) /$ with lexically floating tone. In those cases where Rule 2 does not apply, $/ \mathrm{L}(\mathrm{H}) /$ changes to /LH/ before $\mathrm{L}-$ this is Rule 4 as formulated here. However, one could assume that the underlying pattern is $/ \mathrm{LH} /$. The set of rules would be different in this case: /LH/ changes into $[\mathrm{H}]$ after $\mathrm{H}$ (Rule 2 modified), and the rest of / $\mathrm{LH} /$ melodies delink $\mathrm{H}$ before $\mathrm{H}$ and before pause (Rule 4 modified). The advantage of such an interpretation is that it is more typologically common - as noted in Hyman (2007), tone anticipation which we have to postulate for $/ \mathrm{L}(\mathrm{H}) /$ otherwise is almost non-existent in West African languages and it is not very common cross-linguistically. However, postulating lexical $/ \mathrm{L}(\mathrm{H}) /$ has some advantages as well. First, it is psycholinguistically more adequate $/ \mathrm{L} \%$ is the way these lexemes are pronounced in isolation and, apparently, perceived by native speakers. A stronger argument, however, is that there is a separate /LH/ pattern in Kpelle which does not demonstrate any delinking. Postulating $/ \mathrm{L}(\mathrm{H}) /$ and $/ \mathrm{LH} /$ captures this contrast.
} 
$/ \mathrm{L}(\mathrm{H}) / \rightarrow[\mathrm{LH}] / \_\mathrm{L}$

(60) /nàlă kòl’̌/ $\rightarrow$ /nàlá kòlò\% 'the lion's skin'

(61) /yàà tòò/ $\rightarrow$ [yàá tòò ${ }^{\circ}$ 'I have fallen', cf. also (36)

As the reader may have noticed, phonological contexts where regressive $(\mathrm{H})$ linking could apply coincide partly with contexts where Rules 1 and 2 apply as shown in (62-64):

(62) Rule 1: /L(H)/ +/L/ $\rightarrow \mathrm{L}+\mathrm{HL}$

(63) Rule 2: /L(H)/ +/L(H) $\rightarrow \mathrm{L}+\mathrm{H}$

(64) Rule 4: /L(H)/ + L $\rightarrow \mathrm{LH}+\mathrm{L}$

Again, speaking in terms of rule interaction, Rules 1 and 2 bleed Rule 4 reducing the number of contexts where it can apply. In other words, Rule 4 applies after Rules 1 and 2 and, crucially, in those contexts where the latter do not operate. This is illustrated in (65):

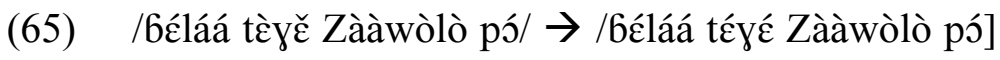

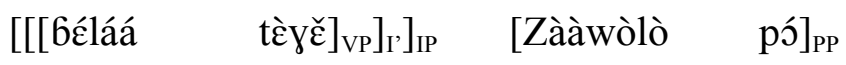
sheep give Zaawolo to

'Give a sheep to Zaawolo'.

In (65) the following combination of melodies is shown: /H/ +/L(H)/ / / $/+/ H /$. As [6éláá tèy $\bar{\varepsilon}_{\mathrm{VP}}$ is a verb phrase, $\mathrm{H}$ spreads on $/ \mathrm{L}(\mathrm{H}) /$ within this syntactic constituent so we get $[\mathrm{H}]+[\mathrm{H}]$ $+[\mathrm{L}]+[\mathrm{H}]$. Context for Rule 4 is deleted so it does not apply. Consider (66):

(66) /nààlèè tèyč Zààwòlò pó/ $\rightarrow$ [nààlèè tèy $\varepsilon$ Zààwòlò pó]

$\left[\left[[\text { nààlèè } \quad \text { tèyě }]_{\mathrm{VP}}\right]_{\mathrm{r}}\right]_{\mathrm{IP}} \quad[\text { Zààwòlò } \quad \text { pó }]_{\mathrm{PP}}$

cat give Zaawolo to

'Give a cat to Zaawolo'.

In (74) there is $/ \mathrm{L} /+/ \mathrm{L}(\mathrm{H}) /+/ \mathrm{L} /+/ \mathrm{H} /$. No $\mathrm{H}$ tone spreads in the verb phrase, so Rule 4 applies between the verb and postpositional phrase which yields $[\mathrm{L}]+[\mathrm{LH}]+[\mathrm{L}]+[\mathrm{H}]$.

Crucially, regressive $(\mathrm{H})$ linking can occur across syntactic boundaries - between the subject noun phrase and the auxiliary (67), the auxiliary and the verb phrase (61), the auxiliary and the direct object (68), between the verb phrase and the postpositional phrase (66), between the postpositional phrase and the adverb (69): 
(67) / / kèě àă kéléń/ $\rightarrow$ [kèć àà kéléń]

$[\mathrm{kè \varepsilon ̌}]_{\mathrm{NP}}[\text { àă kéléń }]_{\text {I' }}$

field 3SG.RES.P burn

'The field has burned'.

(68) / /yàă jààlèè káá/ $\rightarrow$ /yàá jààlèè káá/

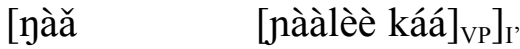

1SG.RES.P cat see

'I saw a cat'.

(69) /ă hèè Pépèè kwèlě kèlèkèlè/ $\rightarrow$ /à héé !Pépèè kwèlé kèlèkèlè/

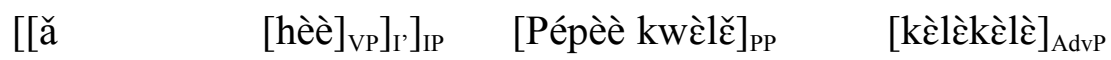

3SG.HAB.P sit $\backslash$ HAB Pepe near often

'He often sits near Pepe'.

In fact, in (69) three rules discussed above apply: H spread on the verb /hèè/ which gives [héè], contour simplification yielding downstepped H on Pépèè, and regressive $(\mathrm{H})$ linking on /kwèlı̌l. In (70) a step-by-step tonal derivation for (69) is shown:

(70) /ă hèè Pépèè kwèlě kèlèkèlè/ $\rightarrow$ [ă héè Pépèè kwèlě kèlèkèlè] $\rightarrow$ [ă héé !Pépèè kwèlě kèlèkèlè] $\rightarrow$ [ă héé !Pépèè kwèlé kèlèkèlè]

However, regressive $(\mathrm{H})$ linking can never cross a clause boundary:

(71) /ă hèè Pépèè kwèlě yč yì̀ $\rightarrow$ /à héé !Pépèè kwèlè yè yîl/

$\begin{array}{lllll}{[[[\text { ă }} & \left.\left.[\text { hèè }]_{\mathrm{VP}}\right]_{\mathrm{I}}\right]_{\mathrm{IP}} & \left.[\text { Pépèè kwèl }]_{\mathrm{PP}}\right]_{\mathrm{IP}} & {[\mathrm{y} \varepsilon} & \text { yì̀ }]_{\mathrm{IP}} \\ \text { 3SG.HAB.P } & \text { sit } & \text { Pepe near } & \text { 3SG.CONJ } & \text { sleep } \backslash \text { HAB } \\ \text { 'He (usually) } & \text { sits near Pepe and sleeps'. } & & \end{array}$

In (71) the utterance consists of two separate clauses - the first has a habitual positive auxiliary $a$, in the second one the auxiliary yě marks a concomitant event. The structure for (71) is given in (72): 
(72)

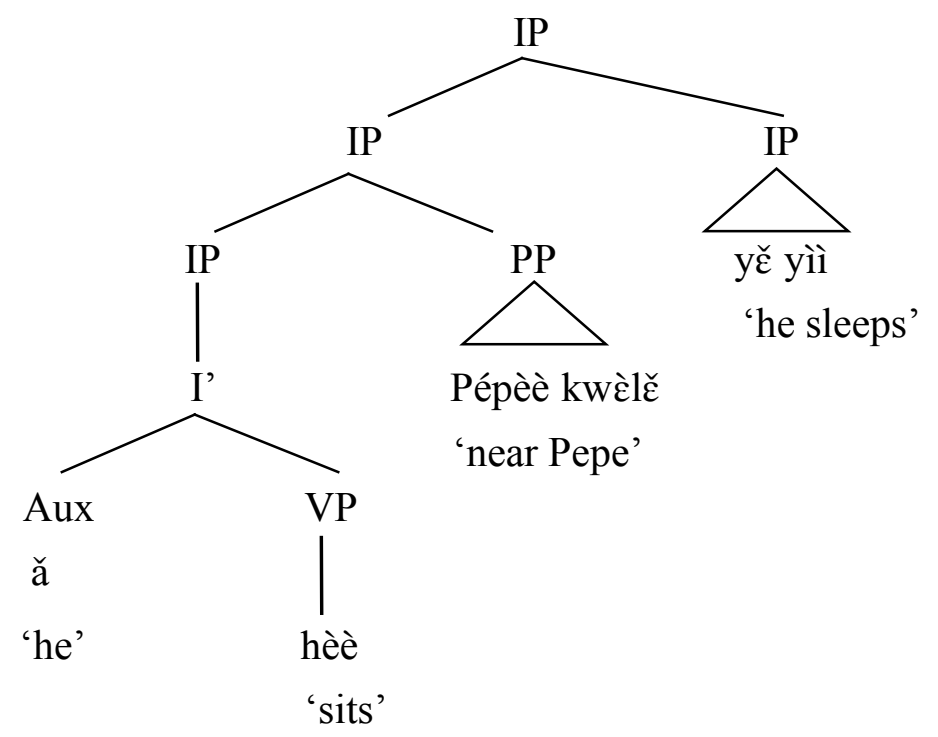

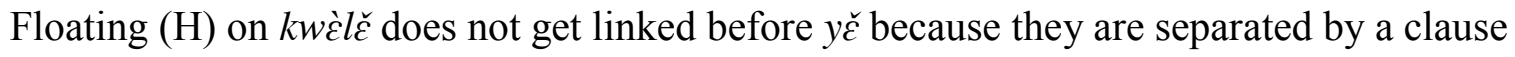
boundary.

The rules discussed in 3.1-3.4 are represented schematically in (73):

$$
\begin{aligned}
& \text { Rule domain: } \\
& \text { syntactic constituent }
\end{aligned}
$$

clause

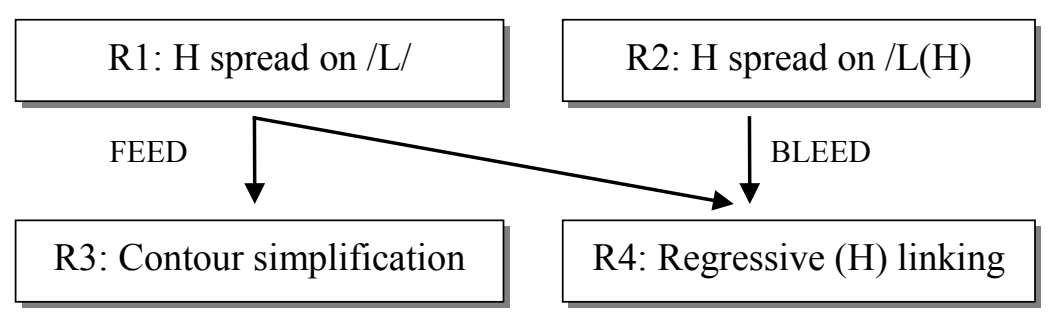

Scheme (73) shows that there are two groups of tone rules in GK: those applied within a syntactic constituent and those applied within a clause. The first group consists of $\mathrm{H}$ spread rules $-\mathrm{H}$ spread on /L/ (Rule 1) and /H/ spread on /L(H)/ (Rule 2). Rule 1 and, marginally, Rule 2 - in the case of lèe shown in (44) - feed Rule 3, which simplifies contours within a clause. At the same time, these rules bleed Rule 4 which links floating $(\mathrm{H})$ regressively before $\mathrm{L}$ within a clause $^{8}$.

\section{Conclusion}

In this article I have discussed the interaction between syntactic structure and tone rules in GK. First of all, I have demonstrated that GK has a cluster of non-trivial syntactic features

8 In fact, there are two more prosodic rules in Kpelle: downdrift operating within an utterance which I do not discuss here in detail because it does not change tone contrasts categorically, and optional clause-final $\mathrm{H}$ which seems to be an instance of intonation. 
including a strict SAuxOVX word order and clause-external postpositional phrases (Section 1). Second, I have shown that tone is organized in six fixed melodies in the language which can undergo surface changes (Section 2). There are four rules accounting for surface changes of tone in GK, namely $\mathrm{H}$ tone spread on /L/, H tone spread on /L(H)/, Contour simplification, and Regressive $(\mathrm{H})$ linking (Section 3). I argue that there is a strong correspondence between syntax and tonal rules in the language. The first two rules apply within syntactic constituents, the second two rules operate within clause. A mismatch is, however, also attested: $\mathrm{H}$ tone can spread from auxiliary to intransitive verb though they do not seem to form a syntactic constituent together. Thus it is reasonable to postulate separate prosodic constituents for GK, such as phonological and intonation phrase, which, however, correspond to syntactic structure in most cases. To conclude, Kpelle data support the "Match" model of phonology-syntax interface as argued in Selkirk $(2009,2011)$ which calls for a correspondence between syntactic and prosodic constituents.

\section{References}

Castelain, Jules. 1952. La langue guerzé : Grammaire et dictionnaire. Dakar : Mémoires de l'IFAN, 20.

Creissels, Denis. 2005. S-O- $V-X$ constituent order and constituent order alternations in West African languages. Berkeley Linguistics Society 31: Special session on languages of West Africa, pp. 37-51.

Dobashy, Yoshihito. 2003. Phonological phrasing and syntactic derivation. Ph.D. dissertation, Cornell University.

Downing, Laura. 2013. Issues in the phonology-syntax interface in African languages. In Olanike Ọla Orie and Karen W. Sanders, eds., Selected Proceedings of the $43^{\text {rd }}$ Annual Conference on African linguistics: Linguistic interface in African languages, pp. 26-38.

Dryer, Matthew S. and Orin Gensler. 2005. Order of object, oblique, and verb. In Martin Haspelmath, Matthew S. Dryer, David Gil \& Bernard Comrie, eds., The world atlas of language structures. pp. 342-345. Oxford: Oxford University Press.

Elordieta, Gorka. 1997. Morphosyntactic Feature Chains and Phonological Domains. Ph.D. dissertation, University of Southern California.

Elordieta, Gorka. 2007. Segmental phonology and syntactic structure. In Gillian Ramchand \& Charles Reiss, eds., The Oxford Handbook of linguistic interfaces, pp. 125-178. Oxford: Oxford University Press.

Hyman, Larry. M. 2007. Universals of tone rules: 30 years later. In Tomas Riad \& Carlos

Gussenhoven, eds., Tones and tunes: Studies in word and sentence prosody, pp. 1-34. Berlin: Mouton de Gruyter.

Inkelas, Sharon and Draga Zec. 1995. Syntax-Phonology Interface. In John Goldsmith, ed., The Handbook of Phonological Theory, pp. 535-549. Oxford: Blackwell.

Innes, Gordon. 1967. Genitival phrases in Mande languages. African Language Studies 8: 
160-167.

Ishihara, Shin. 2003. Intonation and Interface Conditions. Ph.D. dissertation, MIT.

Konoshenko, Maria. 2008. Tonal systems in three dialects of the Kpelle language. Mandenkan 44:21-42.

Konoshenko, Maria. 2013. Lično-čislovoe markirovanije v jazyke kpelle: k tipologii soglasovanija po litsu i čislu. Voprosy jazykoznanija 2013(1):95-114.

Koptjevskaja-Tamm, Maria. 2006. Adnominal possession. In Keith Brown, ed., Encyclopedia of Languages and Linguistics, Second Edition, Vol. 1, pp. 765-769. Oxford: Elsevier.Lassort,

Paul. 1952. Grammaire guerzé. Dakar : Mémoires de l'IFAN, 20.

Letučij, Aleksandr. 2006. Tipologija labil'nyx glagolov: semantičeskie i morfosintaksičeskie aspekty. PhD dissertation, Moscow State University.

Lewis, M. Paul, Gary F. Simons, and Charles D. Fennig (eds.). 2014. Ethnologue: Languages of the World, Seventeenth edition. Dallas, Texas: SIL International. Online version: http://www.ethnologue.com.

Nespor, Marina and Irene Vogel. 1986. Prosodic Phonology. Dordrecht: Foris.

Nikitina, Tatiana. 2008. The mixing of syntactic properties and language change. $\mathrm{PhD}$ dissertation, Stanford University.

Nikitina, Tatiana. 2009. The syntax of postpositional phrases in Wan, an "SOVX" language. Studies in Language 33(4):907-30.

Nikitina, Tatiana. 2011. Categorial reanalysis and the origin of the S-O-V-X word order in Mande. Journal of African Languages and Linguistics 32:251-73.

Nikitina, Tatiana. 2012. Clause-internal correlatives in Southeastern Mande: A case for the propagation of typological rara. Lingua 122(4):319-34.

Seidl, Amanda. 2001. Minimal Indirect Reference: A Theory of the Syntax-Phonology Interface. London: Routledge.

Selkirk, Elisabeth O. 1980. The role of prosodic categories in English word stress. Linguistic Inquiry 11:563-605.

Selkirk, Elisabeth O. 2009. On clause and intonational phrase in Japanese: The syntactic grounding of prosodic constituent structure. Gengo Kenkyu 136:35-74.

Selkirk, Elisabeth O. 2011. The syntax-phonology interface. In John Goldsmith, Jason Riggle, and Alan C. L. Yu, eds., The handbook of phonological theory, pp. 435-484. Oxford: Blackwell Publishing.

Welmers, William. 1962. The Phonology of Kpelle. Journal of African Languages 1 (1):69-93. Welmers, William. 1973. African language structures. Berkeley \& Los Angeles: University of California Press.

Vydrin, Valentin. 2010. Eščë raz o "subjektnyx mestoimenijax" v južnyx mande: mestoimenija ili predikativnye pokazateli? In Viktor A. Vinogradov, ed., Osnovy afrikanskogo jazykoznanija: sintaksis imennyx i glagolnux grupp. pp. 385-400. Moscow: Academia. Vydrin, Valentin. 2012a. Aspektual'nye sistemy južnyx mande v diaxroničeskoi perspective. Acta Linguistica Petropolitana 8, 2 (2012):566-647. 
Vydrin, Valentin. 2012b. Predglagol'nye narečia v bamana. In Valentin Vydrin, Aleksandr Želtov, eds., Meždu Nigerom i Kongo: Zametki na pol'ax k 60-letiu Konstantina Igoreviča Pozdn'akova, pp. 79-93. St. Petersburg: Nestor-Istoria. 